\title{
PENERAPAN PERSONAL SELLING PADA STRATEGI PENJUALAN MOTOR HONDA DI CV. SUMBER MAS MOTOR AMBULU
}

\author{
KASKOJO ADI* \\ ANA YUNITA \\ Program Studi Ilmu Administrasi Niaga \\ Sekolah Tinggi Ilmu Administrasi Pembangunan Jember \\ *Email: kaskojo@stiapembangunanjember.ac.id
}

\begin{abstract}
ABSTRAK
Tujuan penelitian ini untuk mengetahui strategi personal selling dalam proses penjualan motor honda pada CV Sumber Mas Motor. Personal selling adalah aktivitas personal yang dilakukan oleh seorang penjual melalui sales dengan tujuan untuk menarik pelanggan, menjual, dan membangun hubungan dengan pelanggan. Penelitian ini merupakan penelitian kualitatif dengan pendekatan studi kasus. Teknik penentuan informan menggunakan metode purposive, informan untuk penelitian ini dipilih peneliti karena memiliki kompetensi dibidangnya. Pengumpulan data dilakukan melalui observasi, wawancara, dan dokumentasi. Metode analisis data mencakup kondensasi data, penyajian data, dan penarikan kesimpulan. Kesimpulan dari penelitian ini adalah bahwa personal selling yang dilakukan oleh CV Sumber Mas Motor melalui tahapan-tahapan, diantaranya memilih dan menilai prospek, pra pendekatan, pendekatan, presentasi/demontrasi, mengatasi keberatan, penutupan, dan tindak lanjut.
\end{abstract}

Kata Kunci: Personal Selling, Strategi, Penjualan 


\section{PENDAHULUAN}

Perkembangan dunia usaha dewasa ini diwarnai dengan persaingan yang ketat. Situasi ini mencerminkan iklim dunia yang berkembang dan bergerak cepat. Berbagai cara serta strategi telah dilakukan guna menghadapi tantangan, persaingan yang dikembangkan oleh manager pemasaran sebagai ujung tombak perusahaan dalam menghadapi persaingan dalam bidang pemasaran.

Pemasaran dalam suatu perusahaan merupakan salah satu faktor yang penting dan turut menentukan kelangsungan hidup bagi suatu perusahaan sebab kegagalan dalam memasarkan barang akan berakibat fatal, keuntungan yang diharapkan tidak akan tercapai. Bagian pemasaran sebagai ujung tombak suatu perusahaan diharapkan untuk mampu mendistribusikan produknya dengan cara yang seefektif dan seefisien mungkin, sehingga mampu merealisasikan tujuan perusahaan baik untuk jangka pendek dan jangka panjang. Oleh karena itu, prinsip dari pemasaran adalah suatu organisasi hanya dapat mencapai tujuannya jika memahami kebutuhan dan keinginan pelanggan dan mampu memenuhinya dengan cara yang lebih efisien dan lebih efektif dibandingkan dengan pesaingnya (Simamora, 2003: 20).

Perusahaan tentu mempunyai tujuan tersendiri. Tujuan tersebut adalah untuk dapat tumbuh dan berkembang dengan baik. Tujuan ini hanya dapat dicapai melalui usaha mencari keuntungan atau laba perusahaan semaksimal mungkin dengan usaha dan pengorbanan tertentu. Hal ini dapat dicapai melalui usaha mempertahankan dan meningkatkan daya kemampauan perusahaan baik dalam menghadapi persaingan maupun dalam usaha mengefisiensikan usaha. Salah satu yang dapat dilakukan adalah meningkatkan penjualan melalui usaha mencari, membina serta menguasai pasar.

Proses penjualan dalam sebuah bisnis juga sangat penting. Perusahaan tentu harus melakukan proses penjualan yang baik agar mendapatkan keuntungan dalam keberlangsungan organisasinya. 
Produk yang baik akan menjadi siasia manakala proses penjualannya tidak baik. Personal Selling (Penjualan personal) menurut Kotler dan Armstrong (2008: 182) merupakan presentasi pribadi oleh tenaga penjual perusahaan dengan tujuan melakukan penjualan dan membangun hubungan yang baik dengan para pelanggan, baik pelanggan lama maupun pelanggan baru. Personal Selling juga merupakan alat promosi yang sifatnya lisan, baik kepada seseorang maupun calon pembeli dengan maksud untuk menciptakan terjadinya transaksi pembelian yang saling menguntungkan bagi kedua belah pihak.

Dealer Honda yang ada di Kabupaten Jember berjumlah delapan, yaitu Main Dealer (MPM Diponegoro, MPM Kebonsari) dan Sub Dealer (Sumber Mas Motor, Surya Gemilang Motor, Gunawan, Sekawan, Jaya Abadi, Karunia Sejahtera Motor). Persaingan masing-masing Dealer tentu sangat kompetitif. Dealer harus memiliki strategi tersendiri untuk memenangkan persaingan. Salah satu strategi yang bisa dilakukan adalah melalui strategi Personal Selling (penjualan personal).

CV Sumber Mas Motor merupakan dealer motor yang khusus menjual produk Honda. Lokasinya berada di Kabupaten Lumajang dan memiliki cabang di Jl Suyitman No 150 Kecamatan Ambulu Kabupaten Jember, serta merupakan satusatunya dealer Honda di Kecamatan Ambulu. Produk yang dijual juga sama dengan dealer-dealer Honda lain, diantaranya matic, cup, dan sport. CV Sumber Mas Motor cabang Ambulu memiliki tenaga penjual berjumlah 16 orang, yang terdiri dari sales lapangan dan sales counter.

Sales adalah ujung tombak dari suatu perusahaan. Melalui petugas lapangan perusahaan dapat mengetahui keinginan dan tuntutan yang sedang ada pada konsumen. Termasuk tuntutan konsumen terhadap produk/jasa yang dipasarkan oleh suatu perusahaan. Melalui tenaga lapangan ini juga perusahaan mendapatkan order pembelian barang (Wardana, 2008: $1)$. 
Penjualan motor Honda pada suatu dealer juga tergantung pada kekuatan salesnya, karena dimanapun dealer honda berada tentu menjual jenis yang sama, yaitu motor Honda. Tidak ada dealer honda yang menjual produk yang berbeda. Tidak ada persaingan antar dealer dalam sisi produk (kualitas motor, varian motor, dan kenyamanan motor). Artinya bahwa salah satu persaingan kekuatan pada dealer adalah terletak dalam strategi menjualnya yang dilaksanakan oleh seorang sales.

Fenomena yang terjadi pada CV Sumber Mas Motor cabang Ambulu secara berturut-turut penjualannya tidak memenuhi target. Target yang diberikan pada CV Sumber Mas Motor cabang Ambulu setiap tahunnya terus meningkat, tetapi

\section{TINJAUAN PUSTAKA}

\subsection{Manajemen Pemasaran}

Menurut Purwanto (2012 : 8), manajemen adalah proses pengkoordinasian kegiatan-kegiatan pekerjaan, sehingga pekerjaan tersebut terselesaikan secara efektif dan efisien dan dengan melalui orang lain. Manajemen merupakan sebuah belum ada satupun tiap tahunnya yang dapat memenuhi target penjualan dealer.

Seorang sales merupakan aktor utama dalam melakukan kegiatan personal selling. Target yang tidak tercapai menjadi suatu permasalahan yang bisa diangkat oleh peneliti untuk di analisis bagaimana sebenarnya proses kegiatan personal selling dalam CV Sumber Mas Motor sehingga target yang dibebankan kepada dealer tidak tercapai. Pencapaian target tentu sangat penting untuk keberlangsungan dealer sendiri. Oleh karena itu, permasalahan inilah yang menjadi fenomena yang layak untuk dilakukan kajian ilmiah tentang strategi personal selling pada CV Sumber Mas Motor cabang Ambulu.

proses untuk mengatur sesuatu yang dilakukan oleh sekelompok orang atau organisasi untuk mencapai tujuan organisasi tersebut dengan cara bekerja sama memanfaatkan sumber daya yang dimiliki.

Pemasaran adalah sistem keseluruhan dari kegiatan usaha yang 
ditujukan untuk merencanakan, menentukan harga, mempromosikan dan mendistribusikan barang dan jasa yang dapat memuaskan kebutuhan pembeli. Pada dasarnya pemasaran berkaitan dengan proses sosial dan managerial yang membuat individu dan kelompok memperoleh apa yang mereka butuhkan dan inginkan lewat penciptaan dan pertukaran timbal balik produk (Purwanto, 2012: 9).

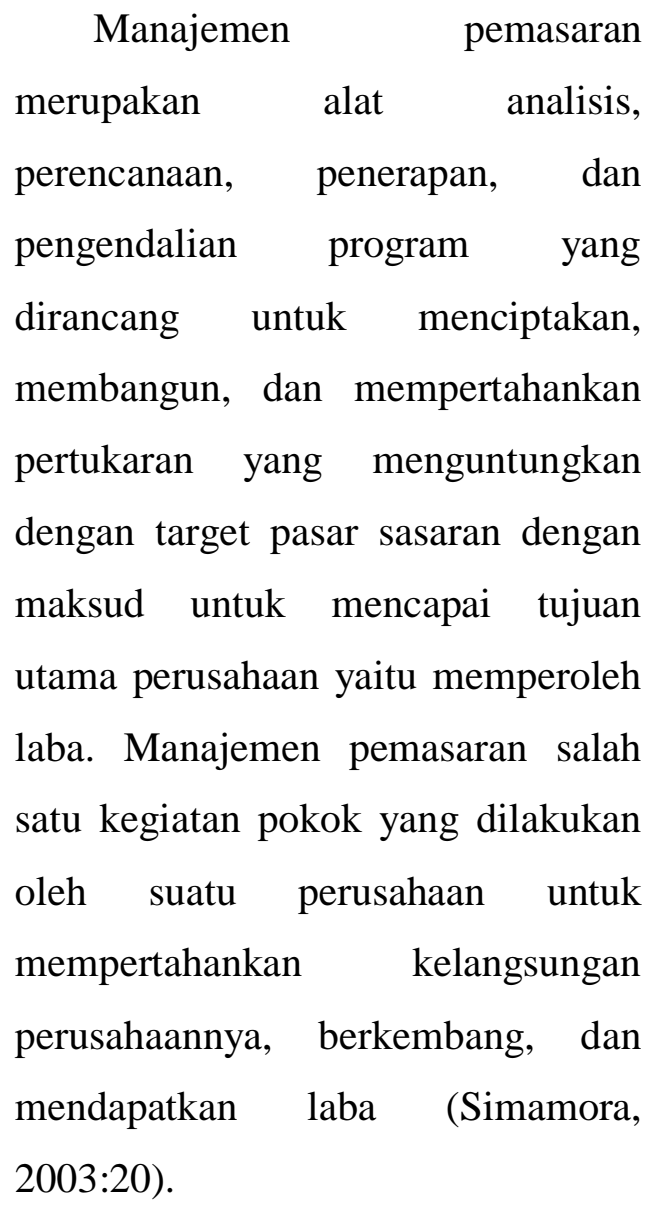

\subsection{Bauran Pemasaran}

Bauran pemasaran merupakan campuran dari variabel-variabel pemasaran yang dapat dikendalikan, digunakan oleh suatu perusahaan untuk mengejar tingkat penjualan yang diinginkan dalam pasar sasaran. Menurut Suhendi dan Sasangka (2014:71), bauran pemasaran yaitu mencakup konsep dasar dalam pemasaran, dimana didalamnya memuat tentang tahapan-tahapan pemasaran suatu produk atau jasa. Tahapan-tahapan dalam bauran pemasaran ini secara umum dikenal dengan istilah '4P' yakni, Produk, Price, Place dan Promotion.

Setiap perusahaan pasti melakukan proses pemasaran. Proses inilah yang menjadikan barang dari produsen bisa sampai ke tangan konsumen. Perlu adanya strategi khusus dalam menjalankan proses ini. Fokus kegiatan ini adalah konsumen. Pelayanan konsumen diperhatikan sebaik mungkin demi mencapai keberhasilan pemasaran. Strategi yang biasa digunakan adalah bauran pemasaran. Tak pernah dipungkiri bahwa pemasaran masih memiliki pesan penting dalam sebuah bisnis. Dengan adanya 
pemasaran dapat membantu memberikan informasi mengenai barang atau jasa yang ditawarkan sebuah perusahaan, sehingga dapat memenuhi kebutuhan dan keinginan konsumen sesuai dengan sasaran pasar. Produk barang atau jasa akan memiliki nilai jual yang lebih tinggi, jika kita dapat menyediakan apa yang konsumen butuhkan (Suwarno, 2011:171).

Para pengusaha yang kreatif, akan selalu menciptakan kombinasi yang terbaik dari elemen $4 \mathrm{P}$ yang menjadi komponen bauran pemasaran. Mereka harus menciptakan dari masing-masing elemen $\mathrm{P}$ yang mana yang paling baik, dan paling banyak digunakan dalam strategi pemasarannya. Antara promosi dan produk, tidak dapat dipisahkan, ini dua sejoli yang saling berangkulan untuk suksesnya pemasaran. Disini harus ada keseimbangan, produk baik, sesuai dengan selera konsumen, bersamaan dengan teknik promosi yang tepat akan sangat membantu suksesnya usaha pemasaran (Alma, 2014:202).

\subsection{Bauran Promosi}

Bauran promosi merupakan salah satu bagian dari bauran pemasaran pada ilmu manajemen pemasaran. Promosi merupakan bagian yang tidak bisa dipisahkan pada pemasaran itu sendiri, sehingga tanpa keberadaannya pemasaran sama sekali tidak bisa berjalan (Marwanto, 2015:131)

Promosi juga merupakan alat yang digunakan untuk mengenalkan suatu produk, baik barang maupun jasa untuk memengaruhi konsumen agar tertarik dan mau membeli produk yang ditawarkan perusahaan. Bauran promosi diantaranya periklanan, publisitas, promosi penjualan, pemasaran langsung, dan personal selling.

\subsection{Strategi Personal Selling}

Istilah strategi berasal dari bahasa Yunani Strategos atau strategus dengan kata jamak strategi. Strategos berarti jendral tetapi dalam bahasa Yunani kuno sering berarti perwira negara (state officer) dengan fungsi yang luas. Pada abad ke 5 SM sudah dikenal adanya Broad of Strategy di Athen, mewakili 10 suku di Yunani. Hingga abad ke 5, 
kekuasaan politik luar negeri dari kelompok strategi itu semakin luas. Lama kelamaan strategi memperoleh pengertian baru (Purwanto, 2012:77).

Strategi merupakan sekumpulan tindakan yang dirancang untuk menyesuaikan antara kompetensi perusahaan dan tuntutan eksternal pada satu industri. Keharusan menyusun strategi adalah untuk mencapai tujuan perusahaan, baik pada jangka menengah maupun jangka panjang. Strategi akan menjamin perusahaan dapat bertahan atau berkembang pada masa yang akan datang (Hamali, 2016:17).

Menurut Rangkuti (2009:68) istilah strategi adalah cara untuk mencapai tujuan. Sedangkan taktik adalah tindakan yang bersifat taktis sesuai dengan kondisi lapangan dalam menunjang strategi yang sudah ditetapkan. Strategi juga merupakan cara terbaik dalam manajemen karena bujet tersebut dapat dengan mudah dievaluasi tingkat keberhasilan sesuai dengan keberhasilan program yang dapat mendukung strategi yang telah ditetapkan untuk mencapai tujuan.
Penjelasan di atas hampir sama dengan apa yang dikatakan oleh Tangkilisan. Menurut Tangkilisan (2007:252) menyatakan bahwa strategi merupakan penyesuaian institusi, organisasi, atau badan pemerintahan terhadap perubahan lingkungan eksternalnya. Institusi atau organisasi yang tidak dapat menyesuaikan diri dengan perubahan yang terjadi pada lingkungan eksternal akan mengalami kemunduran atau kegagalan. Strategi adalah upaya pengembangan keunggulan organisasi atau institusi dalam lingkungan eksternal yang kompetitif untuk pencapaian tujuan atau sasaran organisasi. Strategi dibutuhkan karena adanya perkembangan masyarakat, kemajuan teknologi, dan tuntutan pasar secara keseluruhan.

Kotler dan Amstrong (2008:201) mengatakan secara lebih luas tentang langkah utama dalam penjualan efektif. Langkah tersebut yaitu memilih/menilai prospek, pra pendekatan, pendekatan, presentasi/ demontrasi, mengatasi keberatan konsumen, penutupan, dan tindak lanjut. 
Langkah-langkah utama yang diikuti tenaga penjual ketika melakukan penjualan meliputi, (1) memilih dan menilai prospek (prospecting) ialah langkah awal dalam proses penjualan dimana tenaga penjual mengidentifikasi pelanggan potensial yang berkualitas. Pendekatan terhadap pelanggan potensial yang benar sangat penting bagi keberhasilan. Seorang tenaga penjual harus sering mendekati banyak prospek hanya untuk mendapatkan beberapa penjualan, tenaga penjual juga harus tahu cara menilai (qualify) arahan yaitu, cara mengidentifikasi arahan yang baik dan menyingkirkan arahan yang buruk. Prospek dapat dinilai atau dikualifikasikan dengan melihat kemampuan keuangan mereka, volume bisnis, kebutuhan khusus, lokasi, dan kemungkinan pertumbuhan. Selanjutnya,

langkah tenaga penjual dalam prapendekatan (preapproach) yaitu langkah dalam proses penjualan dimana tenaga penjual belajar sebanyak mungkin tentang pelanggan prospektif sebelum melakukan kunjungan penjualan. tenaga penjual harus menetapkan tujuan kunjungan, yang mungkin untuk menilai prospek, mengumpulkan informasi, atau melakukan penjualan segera.

(3) Pendekatan (approach) merupakan langkah selanjutnya dalam proses penjualan dimana tenaga penjual bertemu dengan pelanggan untuk pertama kalinya dan memulai hubungan dengan baik. Langkah ini memerlukan penampilan tenaga penjual yang baik, kalimat pembuka, dan catatan untuk tindak lanjut. Kalimat pembuka harus positif untuk membangun itikad baik dari awal hubungan. Pembukaan ini bisa diikuti oleh sejumlah pertanyaan kunci untuk belajar lebih banyak tentang kebutuhan pelanggan atau dengan memperlihatkan tampilan atau sampel untuk menarik perhatian dan keingintahuan pembeli. Seperti seluruh tahap proses penjualan, mendengarkan pelanggan adalah hal penting. Langkah selanjutnya, (4) presentasi dan demonstrasi dalam proses ini tenaga penjual menceritakan kisah produk kepada pembeli, menekankan manfaat produk bagi pelanggan. Tenaga 
penjual pencari solusi lebih sesuai dengan konsep pemasaran saat ini daripada tenaga penjual yang gigih menjual atau tenaga penjual murah senyum, hasil bukan omong kosong. Mereka menginginkan tenaga penjual yang mendengarkan kekhawatiran mereka, memahami kebutuhan mereka, dan merespons produk dan jasa yang benar. Pendekatan kebutuhan-kebutuhan ini memerlukan keahlihan mendengarkan dan menyelesaikan masalah yang baik.

$$
\text { Langkah selanjutnya }
$$
mengatasi keberatan dimana tenaga penjual mencari, mengklarifikasi dan mengatasi keberatan pelanggan untuk membeli. Dalam mengatasi keberatan (handling objection), tenaga penjual harus menggunakan pendekatan positif, mencari keberatan tersembunyi, meminta pembeli mengklarifikasi semua keberatan, menganggap keberatan sebagai kesempatan untuk menyediakan lebih banyak informasi, dan mengubah keberatan menjadi alasan membeli. Semua tenaga penjual memerlukan pelatihan keahlihan mengatasi keberatan.
Untuk langkah selanjutnya, (6) yaitu penutupan (closing) dimana tenaga kerja meminta pelanggan mengajukan pesanan. Tenaga penjual harus tahu cara mengenali tanda penutupan dari pembeli, termasuk gerakan fisik, komentar, dan pertanyaan. Tenaga penjual juga bisa menggunakan satu dari beberapa teknik penutupan. Langkah terakhir yaitu dengan cara (7) tindak lanjut (follow up), dalam langkah ini proses penjualan dimana tenaga penjual menindaklanjuti setelah penjualan untuk memastikan kepuasaan pelanggan dan mengulangi bisnis. Tepat setelah menutup penjualan, tenaga penjual harus melengkapi berbagai detail tentang waktu pengiriman, persyaratan pembelian, dan masalah lain. Tenaga penjual kemudian harus menjadwalkan kunjungan tindak lanjut ketika pesanan awal diterima, untuk memastikan adanya instalasi, instruksi, dan pelayanan yang benar.

\subsection{Sales}

Sales adalah dimensi yang mengandung pengertian bahwa setiap orang, setiap departemen, 
setiap lini yang ada dalam sebuah perusahaan adalah sales person. Masing-masing membuat garis koordinasi yang terkait satu sama lain untuk sama-sama menciptakan sales culture. Saat jiwa sales sudah ada di setiap individu, sales culture akan terbentuk. (Tampubolon, 2012:115).

Menurut Tenardhi (2012:13) istilah sales adalah profesi yang dinamis dan hot. Dinamis, karena selalu mengikuti perkembangan pasar dan kebutuhan konsumen yang cenderung cepat berubah sehingga tidak ketinggalan zaman. Hot karena dibangun berdasarkan hubungan emosi, kepercayaan, dan saling menguntungkan dengan pelanggan.

\section{METODE PENELITIAN}

Penelitian ini merupakan jenis penelitian kualitatif. Metode kualitatif lebih berdasarkan pada filsafat fenomenologis yang mengutamakan penghayatan (versheten). Metode kualitatif berusaha memahami dan menafsirkan makna suatu peristiwa interaksi tingkah laku manusia dalam situasi tertentu menurut perspektif
Budiman (2016:156) mengatakan seperti halnya di atas banyak orang yang mengagggap sales sebagai profesi yang rendah sehingga tidak perlu meluangkan waktu untuk belajar. Padahal ilmu sales adalah ilmu yang tidak akan pernah habis dipelajari, dan ilmu paling dinamis karena kita mungkin saja menjual produk yang berbeda-beda, dan juga bertemu dengan orang yang berbedabeda setiap saat.

Menurut Suyanto (2004:29), tujuan gugus wiraniaga (sales) adalah melaksanakan penjualan, yang mencakup seni penjualan tatap muka. Mendatangi konsumen untuk menawarkan produknya.

peneliti sendiri (Usman dan Akbar, 2011:78).

\begin{tabular}{lrr}
\multicolumn{1}{c}{ Jenis } & pendekatan & dalam \\
penelitian & kualitatif & ini, \\
menggunakan & pendekatan studi \\
kasus (case study). Rahardjo dan \\
Gudnanto (2010:16) menjelaskan \\
studi kasus merupakan suatu metode \\
untuk memahami kasus yang \\
dilakukan secara integrative dan
\end{tabular}


komprehensif agar diperoleh pemahaman yang mendalam tentang kasus tersbut beserta masalah yang dihadapinya dengan tujuan masalahnya dapat terselesaikan. Adapun yang membedakan penelitian dengan pendekatan studi kasus dengan jenis pendekatan penelitian kualitatif yang lain terdapat pada kedalaman analisisnya pada sebuah kasus tertentu yang lebih spesifik. Kasus yang dimaksud dalam penelitian ini adalah strategi personal selling yang dilakukan oleh CV Sumber Mas Motor.

Menurut Moleong (2016:132), informan adalah orang yang dimanfaatkan untuk memberikan informasi tentang situasi dan kondisi latar penelitian. Untuk memperoleh kedalaman materi yang disajikan serta validitas data yang diperoleh, maka pemilihan informan menjadi sesuatu yang sangat penting mengingat dari merekalah awal mula data diperoleh dan dikembangkan dalam proses selanjutnya.

Informan dalam penelitian ini dilakukan secara purposive yaitu teknik pengambilan informan sumber data dengan pertimbangan kompetensinya dengan permasalahan dalam penelitian sehingga data yang diperoleh valid. Menurut Bungin (2009:107), purposive adalah teknik pengambilan sumber data dengan kriteria terpilih yang relevan dengan masalah penelitian. Informan yang di pilih merupakan orang-orang yang melakukan personal selling di $\mathrm{CV}$ Sumber Mas Motor.

Menurut Miles dkk (2014:31-33) di dalam analisis data kualitatif terdapat tiga alur kegiatan yang terjadi secara bersamaan. Aktivitas dalam analisis data yaitu: Data Condensation, Data Display, dan Conclusion Drawing atau Verifications.

\section{HASIL PENELITIAN DAN PEMBAHASAN}

Suatu produk yang telah berhasil tentu membutuhkan jasa distribusi untuk memasarkannya. Produk yang telah dihasilkan tersebut tidak bisa mencari konsumen sendiri. Oleh karena itu dibutuhkan strategi pemasaran yang tepat agar suatu produk sukses dipasarkan. Salah satu 
strategi pemasaran yang digunakan CV Sumber Mas Motor adalah dengan cara melakukan personal selling. Faktor keberhasilan dari suatu pemasaran sangat ditentukan dari bagaimana personal selling dilakukan. Jika personal selling yang dilakukan sales dengan tepat sasaran, maka akan menghasilkan penjualan yang sangat signifikan.

Kegiatan personal selling adalah tugas dari seorang sales. CV Sumber Mas Motor dalam melakukan personal selling juga mengandalkan para salesnya. Sales CV Sumber Mas Motor memainkan peranan penting untuk misi penjualan. Keberlangsungan dealer bukan tidak mungkin ada ditangan para sales mereka. Kinerja sales sangat diharapkan untuk melakukan penjualan sebanyak mungkin.

Seorang sales CV Sumber Mas Motor dalam melakukan prospek adalah dengan cara mendatangi tempat-tempat keramaian seperti pasar tradisional di tiap-tiap kecamatan, menghubungi nasabah lama, dan menghubungi broker/perantara. Tempat tersebut dipilih karena banyak peluang untuk melakukan penawaran terhadap konsumen, serta mudah untuk menilai konsumen yang potensial membeli atau tidak. Perantara merupakan orang yang memberikan informasi kepada sales ketika ada seseorang yang ingin membeli motor.

Konsumen yang potensial untuk membeli motor honda akan di hubungi oleh sales. Hal yang dilakukan sales CV Sumber Mas Motor ketika pra pendekatan adalah mencari sebanyak-banyaknya informasi tentang konsumen sebelum melakukan pendekatan. Setelah mendapat informasi yang banyak tentang konsumen (keinginan dan kebutuhan konsumen), cara pendekatan sales CV Sumber Mas Motor kepada konsumen adalah mendatangi/bertemu dengan bersikap sopan serta mendengarkan keinginan dan kebutuhan konsumen tersebut. Cara seperti itu memudahkan sales untuk memahami konsumen secara mendalam sebelum sales CV Sumber Mas Motor menawarkan produknya.

Presentasi dan demontrasi yang dilakukan oleh sales CV Sumber Mas Motor adalah dengan 
mengatakan keunggulan-keunggulan produk honda. Produk honda tentu memiliki keunggulan seperti irit bahan bakar, kualitas baik, dan jaringan bengkel resmi mudah di dapat. Ketika menawarkan produk honda, tentu ada keberatan-keberatan yang di sampaikan oleh konsumen. Keberatan tersebut mayoritas adalah masalah harga. Konsumen meminta harga yang lebih murah. Cara mengatasi keberatan konsumen yang dilakukan adalah dengan cara memberikan potongan harga.

Teknik penutupan sales ketika sudah melakukan penawaran dapat di analisis menjadi dua kemungkinan hasil. Hasil pertama adalah keputusan membeli (deal) dan hasil kedua adalah konsumen belum membeli/tidak membeli. Jika dalam penutupan konsumen sepakat untuk membeli, hal yang dilakukan sales adalah menyiapkan motor yang akan

\section{KESIMPULAN DAN SARAN}

\subsection{Kesimpulan}

Berdasarkan pembahasan hasil penelitian, dapat ditarik beberapa kesimpulan sebagai berikut: dikirim kepada konsumen serta mengurus administrasi pembayaran. Dan jika dalam penutupan konsumen belum tertarik untuk membeli, langkah yang dilakukan adalah tindak lanjut.

Pada dasarnya terdapat dua kategori tindak lanjut yang dilakukan sales terhadap konsumen. Pertama adalah tindak lanjut kepada konsumen yang deal membeli motor. Tindak lanjut yang dilakukan adalah menanyakan kendala dan kepuasan produk. Setelah itu konsumen diminta agar merekomendasikan jika ada teman atau saudara yang hendak membeli motor. Tindak lanjut yang kedua adalah jika dalam penawaran pertama terjadi kebuntuan (konsumen belum membeli). Dalam hal ini seorang sales akan mendatangi (menindak lanjuti) lagi konsumen untuk menawarkan produknya kembali di lain waktu.

1. Strategi sales dalam memilih dan menilai prospek Seorang sales CV Sumber Mas Motor dalam melakukan prospek adalah dengan cara 

mendatangi tempat-tempat keramaian, menghubungi nasabah lama, dan menghubungi broker/perantara. Tempat tersebut dipilih karena banyak peluang untuk melakukan penawaran terhadap konsumen, serta mudah untuk menilai konsumen yang potensial membeli atau tidak.

2. Pra pendekatan sales kepada konsumen

Hal yang dilakukan sales CV Sumber Mas Motor ketika pra pendekatan adalah mencari sebanyak-banyaknya informasi tentang konsumen sebelum melakukan pendekatan.

3. Pendekatan sales kepada konsumen

Cara pendekatan sales CV Sumber Mas Motor kepada konsumen adalah dengan bersikap sopan serta mendengarkan kebutuhan konsumen.

4. Strategi presentasi dan demontrasi

Presentasi dan demontrasi yang dilakukan oleh sales CV Sumber Mas Motor adalah 
7. Tindak lanjut yang dilakukan sales terhadap konsumen Ada dua kategori tindak lanjut, pertama adalah tindak lanjut kepada konsumen yang deal membeli motor. Tindak lanjut yang dilakukan adalah menanyakan kendala dan kepuasan produk. Setelah itu konsumen diminta agar merekomendasikan jika ada teman atau saudara yang hendak membeli motor. Tindak lanjut yang kedua adalah jika dalam penawaran pertama terjadi kebuntuan (konsumen belum membeli). Dalam hal ini seorang sales akan mendatangi (menindak lanjuti) lagi konsumen untuk menawarkan produknya kembali.

8. Faktor keunggulan personal selling CV Sumber Mas Motor Keunggulan yang dimiliki oleh CV Sumber Mas Motor dalam melakukan personal selling diantaranya : CV Sumber Mas Motor memiliki kerja sama dengan banyak Leasing. Konsumen banyak yang membeli dengan sistem kredit, sehingga perusahaan Leasing sangat membantu dealer karena konsumen bisa bebas memilih Leasing yang ingin digunakan. Konsumen yang sebelumnya sudah pernah kredit, bisa memilih kembali Leasing yang sudah pernah digunakan. Selain itu dealer CV Sumber Mas Motor memiliki banyak sales yang sudah berpengalaman.

9. Hambatan-hambatan personal selling CV Sumber Mas Motor Permasalahan yang ada dalam dealer diantaranya : banyak pengajuan kredit yang ditolak oleh Leasing, Sales CV Sumber Mas Motor juga memiliki mobilitas yang rendah (target tidak tercapai), masalah motor yang harus indent/masalah ketersediaan produk, serta minimnya pelatihan peningkatan SDM sales.

\subsection{Saran}

Adapun saran-saran yang dapat diajukan untuk penelitian yang akan datang dapat diuraikan sebagai berikut. 
1. Bagi Perusahaan

a. Setiap sales di CV Sumber Mas Motor hendaknya memiliki buku penjualan pribadi yang berguna sebagai data penjualan.

b. CV Sumber Mas Motor hendaknya mengupayakan ketersediaan produk agar tidak terjadi indent.

c. CV Sumber Mas Motor hendaknya memberikan pelatihan berkala peningkatan Sumber Daya Manusia (sales) tentang penjualan agar pengetahuan bertambah, komitmen bertambah dan dapat bersaing dengan sales dari dealer lain.

\section{DAFTAR PUSTAKA}

Alma, Buchari. 2014. Kewirausahaan. Bandung : Alfabeta.

Budiman, Dedy. 2016. Sales Insight Pride Passion Profit. Jakarta : Gramedia.

Bungin, B. 2009. Penelitian Kualitatif Edisi Kedua. Jakarta : Prenada Media Group.

Hamali, Arif. 2016. Pemahaman Strategi Bisnis Dan Kewirausahaan. Edisi 1, cetakan ke-1. Jakarta : Prenadamedia Group.
2. Bagi Penelitian Selanjutnya Bentuk karya ilmiah ini dapat diteliti lebih mendalam, masih banyak poin pembahasan yang dapat dijadikan materi penelitian selanjutnya. Perusahaan CV Sumber Mas Motor tidak hanya tentang personal selling, di dalamnya masih ada tentang gaya kepemimpinan, komunikasi organisasi, administrasi, dan sebagainya. Hal itu dapat juga dijadikan penelitian selanjutnya sehingga permasalahpermasalahan yang terjadi di CV Sumber Mas Motor semakin mudah untuk dipelajari.
Kotler, Philip dan Gary Armstrong. 2008. Prinsip-prinsip Pemasaran. Edisi 12, jilid ke-2. Jakarta : Erlanngga.

Marwanto, Aris. 2015. Marketing Sukses. Yogyakata : Kobis.

Miles, M. B, Huberman, A. M, dan Saldana, J. 2014. Qualitative Data Analysis A Methods Sourcebook, edisi 3. Jakarta : UIPress.

Moleong, J, Lexy. 2016. Metodologi Penelitian Kualitatif. Bandung : PT Remaja Rosdakarya. 
Purwanto, Iwan. 2012. Manajemen Strategi. Bandung : Yrama Widya.

Rahardjo, Susilo dan Gudnanto. 2010. Pemhaman Individu Teknik Non Tes. Kudus:Noramedia Enterprise.

Rangkuti, Freddy. 2009. Strategi Promosi yang Kreatif dan Analisis Kasus Integrated Marketing Communication. Jakarta : PT Gramedia Pustaka Utama.

Simamora, Bilson. 2003. Memenangkan Pasar Dengan Pemasaran Efektif dan Profitabel. Jakarta : PT. Gramedia Pustaka Utama.

Suhendi dan Indra Sasangka. 2014. Pengantar Bisnis. Bandung : Alfabeta.

Suwarno, 2011. Manajemen Pemasaran Jasa Perusahaan Pelayaran. Edisi 2. Semarang: $\mathrm{CV}$. Indoprint.

Suyanto, M. 2004. Analisis dan Desain Aplikasi Multimedia untuk Pemasaran. Yogyakarta : Andi.

Tampubolon, Remaja. 2012. Sales In You. Jakarta : Gramedia.

Tangkilisan, Hessel. 2007. Manajemen Publik. Jakarta : Grasindo.

Tenardhi, Billy. 2012. Sales Hunter. Jakarta : Raih Asa Sukses.

Usman, Husaini dan Purnomo S Akbar. 2011. Metodologi Penelitian Sosial. Jakarta : Bumi Askara.

Wardana, C, Fikri. 2008. Cara Mudah Menjadi Salesman Idola. Jakarta : Elex Media Komputindo. 